\title{
Soil sterilization, pathogen and antagonist concentration affect biological control of Fusarium wilt of cape gooseberry by Bacillus velezensis Bs006
}

\author{
C. A. Moreno-Velandia $(\mathbb{D} \cdot$ L. F. Izquierdo-García • \\ M. Ongena $\cdot$ J. W. Kloepper $\cdot$ A. M. Cotes
}

Received: 28 August 2017 / Accepted: 31 October 2018/Published online: 12 November 2018

(C) The Author(s) 2018

\begin{abstract}
Background and aim Fusarium wilt (FW) is the major constraint on cape gooseberry (Physalis peruviana L.) production. Fungicides have been ineffective in disease control and alternative tools are not available. Bacillus velezensis (formerly Bacillus amyloliquefaciens) strain Bs006 has an antagonistic potential against Fusarium oxysporum f. sp. physali (Foph). However, results of
\end{abstract}

Responsible Editor: Stéphane Compant.

Electronic supplementary material The online version of this article (https://doi.org/10.1007/s11104-018-3866-4) contains supplementary material, which is available to authorized users.

C. A. Moreno-Velandia $(\bowtie) \cdot$ L. F. Izquierdo-García •

A. M. Cotes

Corporación Colombiana de Investigación Agropecuaria AGROSAVIA, Centro de Investigación Tibaitatá, Kilómetro 14 vía Mosquera-Bogotá, Cundinamarca, Colombia

e-mail: cmoreno@agrosavia.co

L. F. Izquierdo-García

e-mail: 1fizquierdo@agrosavia.co

A. M. Cotes

e-mail: amcotes@agrosavia.co

M. Ongena

Microbial Processes and Interactions Laboratory, University of Liege/Gembloux Agro-Bio Tech, 5030 Gembloux, Belgium e-mail: marc.ongena@ulg.ac.be

J. W. Kloepper

Department of Entomology and Plant Pathology, Auburn University, Auburn, AL 36849, USA

e-mail: kloepjw@auburn.edu in vivo tests have been variable. We examined the effect of biotic sources of variability on the biocontrol activity of Bs006.

Methods Pot experiments in greenhouse were carried out to determine the influence of soil sterilization and concentration of both pathogen and antagonist in soil on biocontrol activity and the effect of pathogen on plant growth promotion by Bs006.

Results Efficacy of Bs006 against FW was significantly lower under sterile than non-sterile soil condition. Diluted liquid culture of Bs006 at $1 \times 10^{6}$ and $1 \times 10^{7}$ cfu. $\mathrm{mL}^{-1}$ reduced $\mathrm{FW}$ by up to $97 \%$ under low Foph inoculum pressure $\left(10^{2}\right.$ to $10^{4} \mathrm{cfu}^{-g^{-1}}$ of soil) but at $1 \times 10^{8} \mathrm{cfu} . \mathrm{mL}^{-1}$ biological treatment significantly reduced FW only when the concentration of Foph was $1 \times 10^{4}$ cfu.g ${ }^{-1}$ by $71 \%$. The evaluation of biomass of Bs006 $\left(1 \times 10^{8} \mathrm{cfu} . \mathrm{mL}^{-1}\right)$ and supernatant free of bacteria added at $10 \%$ allowed to observe that the supernatant was an additional source of biocontrol variability, since high volumes of supernatant favored the development of the disease. Plant growth promoting activity by $\mathrm{Bs} 006$ was reduced by the presence of Foph in the soil. Bs006 grew endophytically in cape gooseberry and had high population levels in the rhizosphere inoculated with Foph.

Conclusions The efficacy of Bs006 to reduce FW was affected by soil sterilization, the concentration of both antagonist and pathogen, and high volumes of supernatant. This work has practical implications for the design of control strategies based on B. velezensis $\mathrm{Bs} 006$. 
Keywords Dose-response relationship · Biological control $\cdot$ Vascular wilting $\cdot$ Golden berry

\section{Introduction}

Colombia was the main cape gooseberry (Physalis peruviana) producer and exporter for the 2000-2010 decade (Bonilla et al. 2009). Cape gooseberry is the second most important fruit crop in Colombia mainly due to exports to European countries, and currently its cultivation has also expanded to other countries including Kenya, Zimbabwe, Australia, New Zealand, India and Ecuador (Fischer et al. 2014). Cape gooseberry has become an alternative crop in over 24 countries, due to its nutritional characteristics and medicinal properties (Fischer et al. 2014). However, yield of cape gooseberry in Colombia has decreased from 18 t.ha $^{-1}$ in 2008 to 10 t.ha $^{-1}$ in 2014 (Ministerio de Agricultura 2016) mostly due to Fusarium wilt disease (FW), caused by Fusarium oxysporum (Estupiñan and Ossa 2007; Rodríguez 2013) recently designated f. sp. physali (Foph) (Simbaqueba et al. 2018).

The pathogenic form of F. oxysporum (Sacc.) (W.C. Synder and H.N. Hans.) causes root rot or vascular wilt in host plants and as a group is the fifth most important fungal plant pathogen of scientific-economic importance mainly because of its wide range of hosts (as species complex) and the severe losses in crops of high economic value including tomato, cotton, banana, and melon (Dean et al. 2012). F. oxysporum is considered difficult to manage (Alabouvette et al. 2007; Chandel et al. 2010) because of its host-specificity (as single pathogenic form - formae specialis) (Bosland 1988) whose genetic basis is supported by horizontal transfer of genetic material (Ma et al. 2010; Van Dam et al. 2016), its ability to form resistance structures, its versatility in producing mycotoxins (Bacon et al. 1996; Leslie and $\mathrm{Xu} 2010$ ), its detoxifying ability (Schouten et al. 2004), its resistance to fungicides (Brent and Hollomon 2007), and its ability to overcome host defense responses (Thatcher et al. 2009).

Control of FW of cape gooseberry has exclusively depended on use of chemical fungicides because other control measures such as resistant cultivars have not been developed and biological based products have not been registered. Moreover, cultural controls such as soil solarization or removal of infected plant debris are not commonly practiced by growers. Despite the use of fungicides, FW can, in some instances, lead to complete crop loss (Barrero et al. 2013). Today consumers increasingly demand food free of agrochemical residues and the use of environmentally friendly production processes. Consequently, growers are under pressure to minimize the use of fertilizers and chemical pesticides. Hence, there is a growing interest in alternatives to the use of agrochemicals.

Biological control of Fusarium wilt is a promising alternative, since biological control agents (BCA) may colonize the rhizoplane or the rhizosphere of the plant host (Ahmad and Baker 1987) and interfere in the pathogenesis process (Deacon 1996; Folman et al. 2004). Biopesticides based on plant growth-promoting rhizobacteria (PGPR) are an example of this type of biotechnological development and their use is increasing due to their potential to control plant pathogens (Borriss 2011). An important group of PGPR are Bacillus species that form endospores, making them resistant to stress conditions and allowing them to be formulated with longer shelf-life than for gram-negative biocontrol bacteria that do not form endospores (Lazarovits et al. 2014).

Members of the Bacillus subtilis species complex, such as B. subtilis, B. amyloliquefaciens subsp. plantarum, B. licheniformis and B. pumilus, have been reported to be efficient in plant growth promotion and biological control of plant pathogens (Borriss 2015). This group of bacteria produce a wide range of bioactive compounds, among which cyclic lipopeptides (CLPs) belonging to the surfactin, iturin and fengycin families are recognized for their potential use in biotechnology and biopharmacology (Cochrane and Vederas 2016). CLPs have also been shown to be involved in the colonization process and motility of Bacillus, as well as in the induction of systemic resistance in the host plant (Ongena et al. 2009). These modes of action that protect plants against phytopathogens make this genus attractive for their use as biological control agents. However, the varying effectiveness observed in pathogen management may be due, in part, to unknown biotic and abiotic factors that affect performance in the field. Therefore, there is a strong need for improving the formulation of microbial products aimed at curtailing the impacts of plant pathogens.

B. amyloliquefaciens Bs006 (Gámez et al. 2015) named now as $B$. velezensis $\mathrm{Bs} 006$ according to the phylogenomic analysis from Fan et al. (2017) in which they included the genome sequence of the strain Bs006, 
is a new plant growth promoting and biocontrol agent with potential to minimize the effects of $F$. oxysporum (Zapata et al. 2012). Nevertheless, its variable biocontrol activity against FW of cape gooseberry (Díaz et al. 2012, 2013; Zapata and Díaz 2012) suggested that biotic and abiotic factors of the rhizosphere might affect the expression of traits related to biocontrol but not those related with plant growth promoting activity. The aim of this study was to determine the influence of biotic factors, including soil sterility, concentration of both BCA and pathogen in the soil, on the biocontrol activity of Bs006 against FW of cape gooseberry and to evaluate the effect of Foph strain Map5 (Foph-Map5) on the plant growth promotion activity of Bs006.

\section{Materials and methods}

Plant material

Commercial cape gooseberry seeds (Colombia ecotype) were washed with tap water to remove fungicide coating from the surface and then surface disinfected in $3 \%$ $\mathrm{NaOCl}$ for $20 \mathrm{~min}$ and subsequently washed three times in sterile distilled water (SDW). Disinfected seeds were germinated in sterile humidity chambers (Petri dishes with wet filter paper) incubated for 20 days in a dark room at $30^{\circ} \mathrm{C}$, to obtain seeds with a radicle of approximately $1 \mathrm{~cm}$ long. Germinated seeds were then planted in plastic trays ( 72 cells) filled with autoclaved peat $\left(120^{\circ} \mathrm{C}, 20 \mathrm{PSI}, 30 \mathrm{~min}\right)$. They were maintained for 30-40 days under greenhouse conditions until they had four fully expanded true leaves. During this time the seedlings were watered daily, and a commercial (Tottal ${ }^{\circledR}$, Colinagro S.A., Bogotá) nutritive solution (N 180 - P 100 - K 40 - Ca 0.27 - Mg 12.5 - S 33 - B 1.35 Co 0.03 - Cu 2.70 - Fe 0.32 - Mn 2.30 - Mo 0.09 - Zn 7.80 g. $\mathrm{L}^{-1}$, respectively) was applied by drench $(0.5-$ $\left.2 \mathrm{~mL} . \mathrm{L}^{-1}\right)$ once a week. These seedlings were used for biocontrol tests under greenhouse conditions.

Microorganisms and culture conditions

Strain Bs006 was isolated from healthy cape gooseberry plants in a crop strongly affected by vascular wilt disease (Zapata et al. 2012), it was subsequently identified as B. amyloliquefaciens (Gámez et al. 2015) and currently it is included in the $B$. amyloliquefaciens operational group as B. velezensis species (Fan et al. 2017).
Bacterial cells cultured in Luria-Bertani agar media were stored in a glycerol $(10 \%)$ and peptone $(1 \%)$ solution at $-70{ }^{\circ} \mathrm{C}$ in the microbial germplasm bank of AGROSAVIA at Tibaitatá Research Center. For experimental use, bacteria were plated on Luria-Bertani agar media ((LBA) tryptone $10 \mathrm{~g}($ Oxoid ()$)$, yeast extract $5 \mathrm{~g}$ (Oxoid $($ ) $), \mathrm{NaCl} 10 \mathrm{~g}$ (Merck $®)$, bacteriological agar $18 \mathrm{~g}$ (Oxoid (®) / $1000 \mathrm{~mL}$ ). Then they were subcultured onto fresh LBA (six plates), incubated during $24 \mathrm{~h}$ at $30^{\circ} \mathrm{C}$, and preserved at $4{ }^{\circ} \mathrm{C}$ for a maximum of 6 months. This subculture served as a stock from which new sub-cultures were prepared as a fresh source of inoculum for liquid cultures of Bs006. Foph-Map5 was isolated from cape gooseberry plants showing vascular wilt symptoms and has been shown to be one of the most virulent isolates found in pathogenicity tests on cape gooseberry in Colombia (Rodríguez 2010). For its preservation, a monosporic culture was made in PDA and plugs of mycelia/conidia were stored in the cryopreserving solution mentioned above. For the experiments in this study the fungus was plated on PDA (Merck ${ }^{\circledR}$ ) and incubated for 7 days at $28^{\circ} \mathrm{C}$. Pieces of young mycelia were taken from this culture to inoculate $50 \mathrm{~mL}$ of PDB (Difco ${ }^{\circledR}$ ) in $250 \mathrm{~mL}$ Erlenmeyer flasks and then incubated for 7 days with shaking at $150 \mathrm{rpm}$ at $28{ }^{\circ} \mathrm{C}$. The fermented broth was filtered through two layers of sterile muslin cloth, the recovered suspension was centrifuged (10.000 rpm, $15 \mathrm{~min}$ ), and the pellet containing the microconidia was suspended in cryopreserving solution and stored in sterile plastic vials at $-20{ }^{\circ} \mathrm{C}$. This preserved collection was used as stock to inoculate PDA or PDB $(300 \mathrm{~mL}$ in $1000 \mathrm{~mL}$ Erlenmeyer flasks) to produce the inoculum of Foph-Map5 for the experiments.

In vivo tests of Bs006 against FW of cape gooseberry

The experiments to measure the biocontrol activity of B. velezensis Bs006 against $\mathrm{FW}$ of cape gooseberry were carried out in a glasshouse $\left(56 \mathrm{~m}^{2}\right)$. The average temperature in the glasshouse was $25 \pm 15^{\circ} \mathrm{C}$; the average relative humidity was $60 \pm 15 \%$. For plant growth a substrate mix of soil (Andosol, pH 5.7, MO 12.90, P $\left.11 \mathrm{mg} \cdot \mathrm{Kg}^{-1}, \mathrm{~K} 0.69 \mathrm{cmol}_{(+)} \cdot \mathrm{Kg}^{-1}\right)$ and rice husk $(3: 1$ ratio) was prepared (hereafter referred as the soil). This substrate was moistened with tap water up to $60 \%$ of moisture retention capacity. Sixty days old cape gooseberry seedlings were transplanted and irrigated manually once a day and fertilized ( $30 \mathrm{~mL}$.plant $\left.{ }^{-1}\right)$ at the end of 
the second and fourth week after transplant with diammonium phosphate (DAP Nutrimon ${ }^{\circledR}$, Barranquilla, Colombia, N $18 \%-\mathrm{P} 46 \%-\mathrm{K} 0 \%$ ) at a dose of 6 g. $\mathrm{L}^{-1}$, potassium chloride $\left(\mathrm{KCl}\right.$ Nutrimon ${ }^{\circledR} \mathrm{N} 0 \%$ - P $0 \%-\mathrm{K} 60 \%)$ at dose of 3 g. $\mathrm{L}^{-1}$ and minor nutrients (Borozinco 240GR®, Microfertisa, Bogotá) at 0.5 g. $\mathrm{L}^{-1}$.

\section{Inoculation of microorganisms}

Foph-Map5 inoculum was produced in PDB as described above. The mycelium was discarded and the concentration of microconidia in fermented broth was estimated by counting in a Neubauer chamber. The desired concentration of microconidia for soil inoculations was adjusted as a function of the desired final concentration of inoculum in the soil. For example, using a ratio of $100 \mathrm{~mL}$ of suspension at $1 \times 10^{6}$ microconidia. $\mathrm{mL}^{-1}$ per 0.9 $\mathrm{Kg}$ of wet soil, a concentration of $1 \times 10^{4} \mathrm{cfu} . \mathrm{g}^{-1}$ soil was achieved. Plastic trays containing 12 cones $\left(750 \mathrm{~cm}^{3}\right.$ each) were filled with the uniformly inoculated soil, and one seedling was transplanted per cone. Immediately after transplant, a cell suspension of $B$. velezensis Bs006 obtained from liquid culture (LB, $125 \mathrm{rpm}, 30^{\circ} \mathrm{C}, 48 \mathrm{~h}$ ) was applied to the soil by drench, at a rate of $30 \mathrm{~mL}$.plant ${ }^{-1}$. Bacillus suspensions for soil treatment were prepared by diluting the fermented broth with tap water, hence the treatment contained bacterial cells and metabolites excreted into the medium. The concentration of $\mathrm{Bs} 006$ was adjusted by optical density in a spectrophotometer at $600 \mathrm{~nm}$ (Optizen ${ }^{\circledR}$, Mecasys) and using a standard curve $\left(\mathrm{OD}_{600 \mathrm{~nm}}=0.5 \sim 2.49 \times 10^{8}\right.$ cfu. $\left.\mathrm{mL}^{-1}\right)$.

\section{Evaluation of the effect of soil sterility on Bs006 biocontrol efficacy}

Biocontrol activity of $B$. velezensis Bs006 against FW of cape gooseberry in natural soil was compared with that in sterilized soil $\left(120{ }^{\circ} \mathrm{C}, 20 \mathrm{PSI}\right.$, $30 \mathrm{~min}, 2$ cycles). The concentration of inoculated Foph-Map5 in the soil was $1 \times 10^{4} \mathrm{cfu}^{-\mathrm{g}^{-1}}$. Bs006 was applied at a concentration of $1 \times 10^{8} \mathrm{cfu} \cdot \mathrm{mL}^{-1}$. Plants inoculated only with the pathogen and plants without the pathogen or antagonist were used as negative and absolute controls, respectively.
Analysis of Bs006 and Foph-Map5 concentration on biocontrol activity of $\mathrm{Bs} 006$

The effect of $B$. velezensis Bs006 concentration $\left(10^{5}\right.$ to $10^{9}$ cfu. $\mathrm{mL}^{-1}$ ) on the incidence and severity of FW of cape gooseberry was evaluated in a first experiment. Here the concentration of pathogenic inoculum in the soil was $1 \times 10^{4} \mathrm{cfu}^{-1}$. In a second experiment, the effect of Foph-Map5 concentration $\left(10^{2}\right.$ to $\left.10^{6} \mathrm{cfu}^{-\mathrm{g}^{-1}}\right)$ on biocontrol activity of $\mathrm{Bs} 006\left(1 \times 10^{8}\right.$ cfu. $\left.\mathrm{mL}^{-1}\right)$ was evaluated. Soil sterilization was included in these experiments as a factor to validate the results of the first phase of this investigation. The relationship between lower doses of Bs006 $\left(10^{6}\right.$ and $10^{7}$ cfu. $\left.\mathrm{mL}^{-1}\right)$ and the previous concentrations of Foph-Map5 also was analyzed in a third experiment in non-sterile soil. A fourth experiment was carried out to determine the individual effects of Bs006 cells and supernatant from the LB-broth fermented by Bs006 $\left(30{ }^{\circ} \mathrm{C}, 125 \mathrm{rpm}, 48 \mathrm{~h}\right)$, as well as the effect of the volume $(30,50,100$, and $150 \mathrm{~mL}$ plant $^{-1}$ ) of the treatments on FW development. Inoculum for evaluation of individual effects of Bs006 cells and supernatant was prepared by separating the cells from the fermented broth by centrifugation (15,000 rpm, $15 \mathrm{~min})$. The resulting biomass was washed twice with SDW and centrifuged. Finally, the pellet was resuspended in SDW adjusted to $1 \times 10^{8}$ cfu. $\mathrm{mL}^{-1}$. The supernatant was passed through $0.22 \mu \mathrm{m}$ filters (Millipore ${ }^{\circledR}$, Ireland) and diluted in SDW to a concentration of $10 \%$ before application. A mixed treatment of Bs006 cells $\left(10^{8}\right.$ cfu. $\left.\mathrm{mL}^{-1}\right)$ and supernatant $(10 \%)$ was included, and in this case cell suspension was adjusted in the supernatant solution. Controls in these experiments consisted of plants grown in soil inoculated with pathogen and treated with water (negative control); plants grown in soil free of pathogen and treated with Bs0006 (relative control); and plants grown in soil free of pathogen and antagonist (absolute control).

Effect of Bs006 concentration and presence of Foph-Map5 in the soil on plant growth promoting activity of $\mathrm{Bs} 006$

Cell suspensions of Bs006 in diluted fermented broth at $10^{5}$ to $10^{9}$ cfu. $\mathrm{mL}^{-1}$ were applied to non-sterile soil to measure plant growth variables in nursery and posttransplant conditions in independent experiments. Five $\mathrm{mL}$ of Bs006 suspension were applied to each seedling 
when sowing in the nursery and $30 \mathrm{~mL}$ were applied to 60-day-old plants during transplant for the posttransplant experiment. In a separate experiment, growth of plants transplanted in both non-sterile soil and pathogen-inoculated soil $\left(1 \times 10^{4} \mathrm{cfu} . \mathrm{mL}^{-1}\right)$ and treated

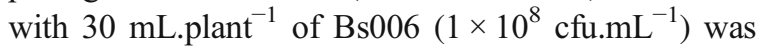
measured.

\section{Measured variables}

The incidence and severity of FW of cape gooseberry were recorded weekly, to note the appearance of typical symptoms of the disease, including loss of turgidity in young leaves, lateral yellowing in old leaves, and stunted plant growth. Disease incidence was expressed as the proportion of plants with typical symptoms of FW. Disease severity assessed the intensity of disease using a $0-5$ scale, modified from Sánchez and Forero (2009), where $0=$ no symptoms of the disease, expanded and turgid leaves with no foliar bending, green leaves; 1 = bending of young leaves, slight epinasty, mild chlorosis of mature leaves; 2 = foliar bending, epinasty in $30-50 \%$ of the leaves, moderate chlorosis in the oldest leaves and slight chlorosis in leaves from the middle of the plant, clear stunting of the plants; $3=$ $60-80 \%$ of leaves show epinasty, clear loss of turgidity, moderate chlorosis in young leaves, abscission of oldest-chlorotic leaves; $4=$ epinasty of all the leaves, severe chlorosis, moderate defoliation, wilting evident; $5=$ twisted leaves, severe wilting, severe defoliation, bent stem, dead plant.

Incidence and severity were calculated by the equations described by Zhang et al. (1996): Incidence $=[($ $\left.\left.\mathrm{n}_{1}+\mathrm{n}_{2}+\mathrm{n}_{3}+\mathrm{n}_{4}+\mathrm{n}_{5}\right) / \mathrm{n}\right] \times 100$ and Severity $=\left[\left(0 \mathrm{n}_{0}+\right.\right.$ $\left.\left.1 \mathrm{n}_{1}+2 \mathrm{n}_{2}+3 \mathrm{n}_{3}+4 \mathrm{n}_{4}+5 \mathrm{n}_{5}\right) / 5 \mathrm{n}\right] \times 100$., where $0-5$ : Degrees of disease; $n_{0}-n_{5}$ : Number of plants in each degree of the disease; $n$ : Total number of plants in the experimental unit. The area under the progress curve of incidence and severity (AUDPC) was calculated according to the equation of Campbell and Madden (1990). The efficacy of treatments in the reduction of incidence and severity of the disease was estimated with equation Efficacy $=[(\mathrm{A}-\mathrm{B}) / \mathrm{A}]^{*} 100$. Where A: AUDPC value of the negative control; B: AUDPC value of a given treatment.

Plant growth variables were measured 30 days after sowing (das) under nursery conditions and 39 days after transplant under post-transplant phase. Root and shot length and number of secondary roots were measured in nursery while shoot length, total leaf area, and root and shot dry weights were measured in post-transplant.

\section{Evaluation of the endophytic ability of Bs006}

To determine the endophytic ability of $B$. velezensis Bs006 and to estimate its population density inside the root and stem tissues, 39 days after inoculation of the pathogen (dai), samples of tissues were taken from plants that were apparently healthy or that had low disease severity (1 or 2 degrees). After removing the rhizospheric soil, the root was washed with a detergent solution, and subsequently the entire main root or $15 \mathrm{~cm}$ of the stem were surface disinfected, following the procedure described by Li et al. (2012) to isolate endophytic strains of Bacillus. Briefly, tissue segments were immersed in $3 \% \mathrm{NaOCl}$ for $10 \mathrm{~min}$, then soaked in ethanol $(70 \%)$ for $1 \mathrm{~min}$ and washed five times with SDW. The sterility of the water from the last root washing was tested by inoculating $50 \mu \mathrm{L}$ aliquots in Petri dishes with LBA which were incubated to examine the presence or absence of microorganism colonies. Sterilized tissue was subsampled by weighing $0.1 \mathrm{~g}$ from the root zone under the crown, from the elongation zone, from the apex and from upper zone of the crown. Each root/stem segment $(0.1 \mathrm{~g})$ was macerated with $1 \mathrm{~mL}$ of SDW in a sterile mortar. A volume of $100 \mu \mathrm{L}$ of the obtained suspension or decimal dilutions were inoculated on three plates with LBA after being subjected to $90{ }^{\circ} \mathrm{C}$ for $10 \mathrm{~min}$ in a thermostatic bath. The plates were then incubated at $30{ }^{\circ} \mathrm{C}$ for $48 \mathrm{~h}$ and the number of milky white and matte colonies with a wrinkled surface was registered. When examined at $400 \mathrm{X}$ magnification under microscopy spore-forming Gram-positive rods were observed. Rhizospheric soil $(0.1 \mathrm{~g})$ also was sampled and suspended in $9.9 \mathrm{~mL}$ sterile Tween 80 solution $(0.1 \% \mathrm{v} / \mathrm{v})$, stirred in a vortex for $2 \mathrm{~min}$, and then submitted to thermal shock and inoculation on LBA as mentioned above.

Experimental design and data analysis

The experiments to test the effect of Bs006 and FophMap5 concentrations on biocontrol activity in sterile and non-sterile soil used a randomized complete blocks design (RCB) with a factorial structure and three to four replicates. The experiment in which the relationship of low concentrations of Bs 006 were tested against several concentrations of Foph-Map5 was evaluated using a $3 \times$ 
5 factorial structure. The factors were the microorganisms (Bs006 and Foph-Map5) and the concentrations were used as the levels of the factors $\left(0,10^{6}\right.$, and $10^{7}$ cfu.mL ${ }^{-1}$ for Bs006, and $10^{2}, 10^{3}, 10^{4}, 10^{5}$, and $10^{6} \mathrm{cfu}^{-\mathrm{g}^{-1}}$ for Foph-Map5). The experiment that was used for evaluating separate effects of Bs006 cells and supernatant had a $3 \times 4$ factorial arrangement with four replicates. The first factor was the biological treatment (cells, supernatant and the mix of both) and the second factor was the applied volume $(30,50,100$, and 150 mL.plant $^{-1}$ ). The experiment in which the effect of Bs006 concentrations on plant growth promotion was measured was carried out under RCB design with three replicates. To measure plant growth variables, sample size of three (nursery) and five plants (post-transplant) per experimental unit were used. The experiment used to evaluate the influence of Foph-Map5 on plant growth promoting responses used a split-plot design with three replicates. The main-plot was the presence of the pathogen and sub-plot was the biological treatment. The sample size for this experiment was three plants per treatment.

The data were submitted to normality test according to Shapiro-Wilk's test $(\alpha=0.05)$ and homogeneity of variances using a Bartlett's test $(\alpha=0.05)$. Significant effects of treatments were determined by analysis of variance (ANOVA) using the generalized lineal model GLM. Tukey's HSD test at $\alpha=0.05$ was used to make comparisons between means of treatments. All analyses were conducted using the Statistical Analysis Software System (version 9.4; SAS Institute, Cary, NC).

\section{Results}

Effect of soil sterilization on biocontrol activity of Bs006

Soil sterilization negatively affected the biocontrol activity of B. velezensis Bs006 against FW of cape gooseberry, since the development of the disease incidence expressed as AUDPC was significantly higher $(P \leq$ 0.01 ) in plants grown in sterile soil compared with the disease development of those grown in non-sterile soil (Fig. 1). The reduction of the disease incidence and severity development (comparing the AUDPC values) by applying Bs006 to non-sterile soil was 80 and $85 \%$, respectively while in sterile-soil the efficacy was 16 and $23 \%$, respectively.

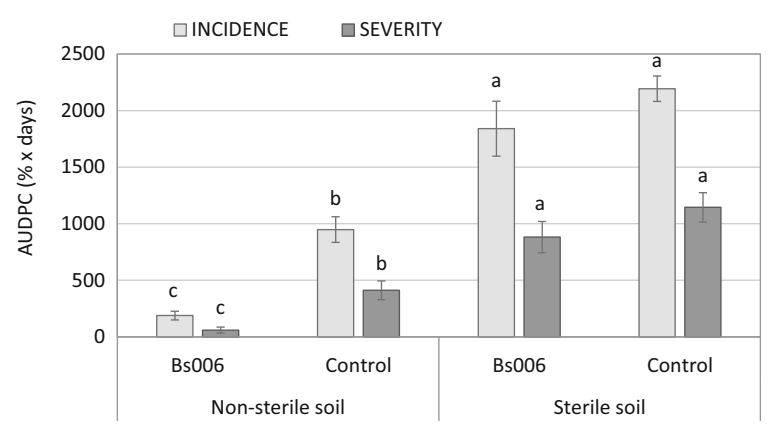

Fig. 1 Effect of the application of $B$. velezensis (Bs006) in natural soil (non-sterile soil) or autoclaved soil (sterile soil) on the development of Fusarium wilt disease (expressed as the area under the incidence and severity progress curve - AUDPC) at 43 days after inoculation. The concentrations of Bs006 and Foph-Map5 were adjusted at $1 \times 10^{8}$ cfu.mL $\mathrm{mL}^{-1}$ and $1 \times 10^{4} \mathrm{cfu}^{-1}$ of soil, respectively. Columns of each variable (incidence and severity) with the same letter are significantly not different according to Tukey test $(\alpha=0.05)$. Bars on the columns represent the standard error of the mean $(n=3)$

The incidence of FW in plants grown in non-sterile soil and treated with Bs006 was $23 \%$ at the end of this experiment (43 dai) while in plants grown in FophMap5 inoculated non-sterile soil and without biocontrol treatment (negative control) the incidence was 63\%, which represents $63 \%$ of efficacy in incidence reduction through the application of Bs006. Meanwhile the disease incidence was $100 \%$ in plants grown in sterile soil both treated and untreated with Bs006 (data not shown). Observations of disease severity showed a similar behavior to the incidence at this endpoint (data not shown).

\section{Effect of Bs006 concentration on biocontrol efficacy}

The application of Bs006 to non-sterile soil showed significant reduction of AUDPC - Incidence $(P \leq 0.05)$ in all tested concentrations compared to the disease in the negative control (Fig. 2a). Under these conditions, the AUDPC - Severity was significantly reduced $(P \leq$ $0.05)$ by Bs006 at $1 \times 10^{6}$ and $1 \times 10^{8} \mathrm{cfu}^{-\mathrm{mL}^{-1}}$ as compared to the negative control. Bs006 $\left(1 \times 10^{8}\right.$ cfu. $\mathrm{mL}^{-1}$ ) reduced the development of $\mathrm{FW}$ incidence and severity by 71 and $80 \%$ (calculated from AUDPC values), respectively, during 49 dai in non-sterile soil. The treatments with Bs006 at $10^{5}, 10^{6}, 10^{7}$, and $10^{9}$ cfu. $\mathrm{mL}^{-1}$ showed efficacy in incidence reduction by $43.3,47.8,42.7$, and $39.3 \%$, respectively and reduction in severity by $42.4,63.0,32.0$, and $36.4 \%$, respectively. Surprisingly, plants treated with Bs006 at $1 \times 10^{9}$ cfu. $\mathrm{mL}^{-1}$ showed similar level of the disease to that of 
the negative control and significantly higher than the rest of concentrations of Bs006 at 56 dai (data not shown). In contrast to non-sterile soil, Bs006 did not reduce FW development in sterile soil (Fig. 2b). However, the reduction of FW development was due to the delay in the onset of the epidemic in non-sterile soil compared with sterile soil (Supplementary material Fig. S1) rather than a reduction in the rate of disease progression (Supplementary material Table S1).

\section{Effect of the concentration of Foph-Map5}

The pathogen was inoculated at concentration ranging from $1 \times 10^{2}$ to $1 \times 10^{6} \mathrm{cfu}^{-g^{-1}}$ in both sterile and nonsterile soil. Biocontrol treatment consisted of application of Bs006 at $1 \times 10^{8}$ cfu.mL ${ }^{-1}$. Bs006 significantly reduced the disease incidence progress $(P \leq 0.05)$ in nonsterile soil only when Foph-Map5 was at $1 \times 10^{4}$ cfu. ${ }^{-1}$. As compared to the respective negative control, no other combination of Foph-Map5 and Bs006 reduced the disease (Fig. 3a). The combination of Bs006 $\left(1 \times 10^{8}\right.$ cfu.mL $\left.{ }^{-1}\right)$ and Foph-Map5 $\left(1 \times 10^{4} \mathrm{cfu}^{-1}{ }^{-1}\right)$ showed an efficacy of 64 and $84 \%$ of reduction of the incidence and severity development of the disease, respectively at 49 dai. Consistent with previous observations in this study, Bs006 did not reduce FW of cape gooseberry in sterile soil (Fig. 3b).

\section{Effect of low concentrations of Bs006 on FW development}

The application of Bs006 at $1 \times 10^{6}$ cfu.mL $\mathrm{mL}^{-1}$ significantly reduced the development of $\mathrm{FW}$ incidence, expressed as the AUDPC value, by 66 and $56 \%$ when the concentration of Foph-Map5 was $10^{2}$ and $10^{3} \mathrm{cfu}^{-1}$ of soil, respectively. Bs006 at $1 \times 10^{7}$ cfu.mL ${ }^{-1}$ reduced the development of FW incidence by 83,93 , and $97 \%$ when Foph-Map5 concentration was $10^{2}, 10^{3}$, and $10^{4}$ cfu.g ${ }^{-1}$, respectively. Low concentrations of Bs006 such as $1 \times 10^{6}$ and $1 \times 10^{7}$ cfu.mL ${ }^{-1}$ efficiently reduced $\mathrm{FW}$ disease under low inoculum pressure of Foph-Map5 but not under higher concentrations of the pathogen in the soil (Fig. 4).
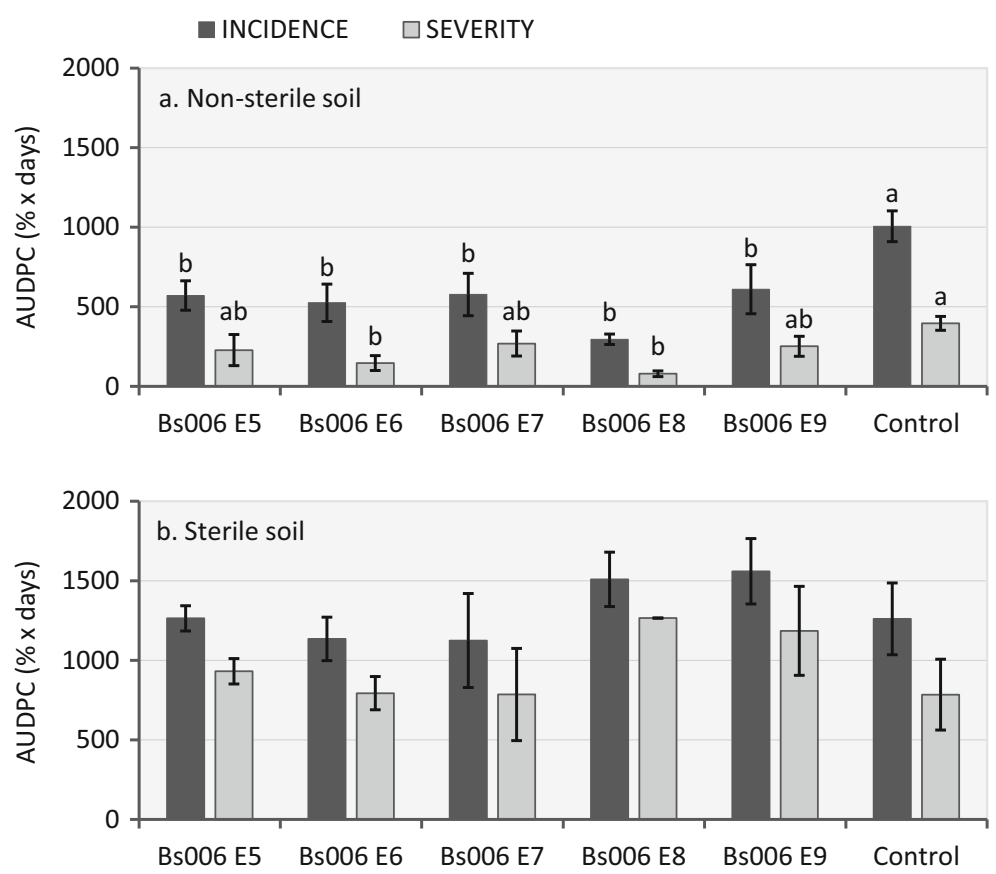

Fig. 2 Effect of B. velezensis Bs006 doses (Bs006 E5: $1 \times 10^{5}$ cfu. $\mathrm{mL}^{-1}$ and so on) on Fusarium wilt incidence and severity (AUDPC: Area under disease progress curve) during 49 days after inoculation in non-sterile (a) and 36 days after inoculation in sterilized soil in autoclave (b). F. oxysporum f. sp. physali Map5 was inoculated in the soil at $1 \times 10^{4} \mathrm{cfu}^{-1} \mathrm{~g}^{-1}$. Control consisted of plants growing in soil inoculated with pathogen and treated with water. Columns of each variable with the same letter are significantly not different according to Tukey test $(\alpha=0.05)$. Significant differences between treatments were not detected for both incidence and severity of the disease under sterile soil. Bars on the columns represent the standard error of the mean $(n=4)$ 


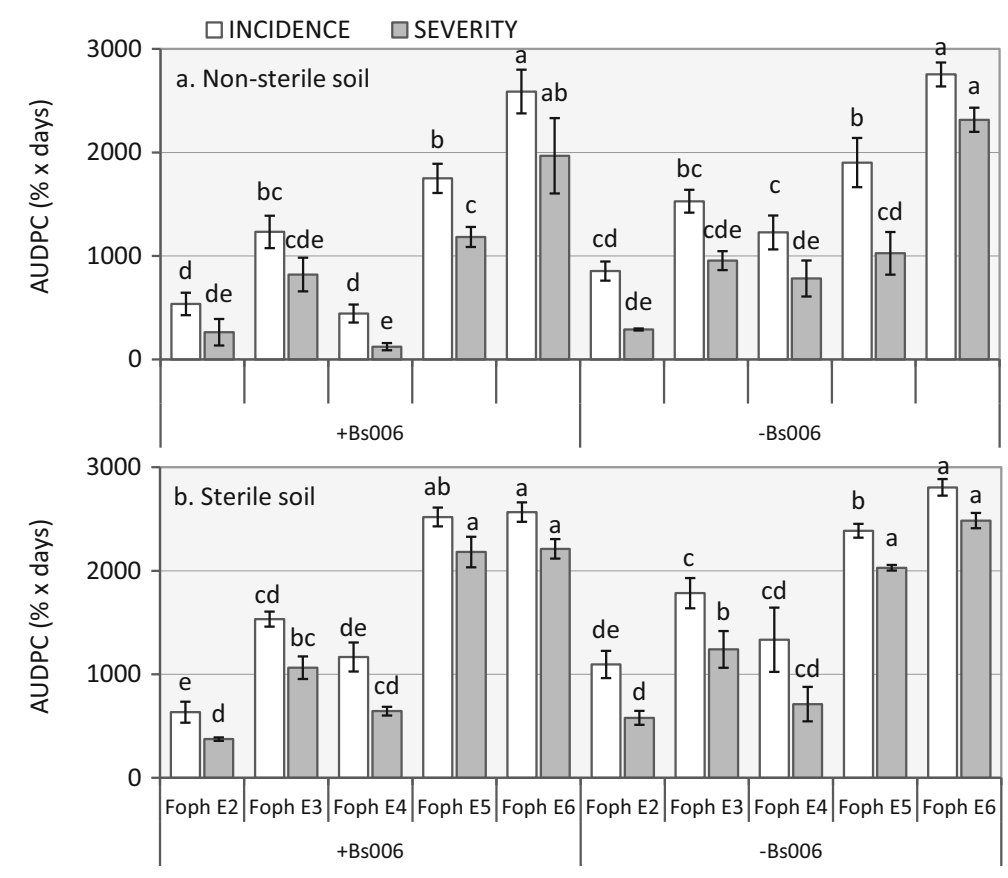

Fig. 3 Effect of inoculum density of $F$. oxysporum f. sp. physali Map5 (Foph) in soil on biocontrol activity of $B$. velezensis Bs006 against incidence and severity progress of Fusarium wilt of cape gooseberry during 49 days after inoculation in non-sterile (a) and sterilized soil (b). $30 \mathrm{~mL}$ of rhizobacteria suspension was applied to the soil after transplant at $1 \times 10^{8}$ cfu. $\mathrm{mL}^{-1}$ by drench (+Bs006). Foph was inoculated on the soil before transplant in concentrations

The interaction of Bs006 and Foph-Map5 concentrations showed significant effects for FW incidence $(P=0.0210)$ but not for severity $(P=0.0935)$ (data not shown).

Individual effect of cells and supernatant of Bs006 culture on FW

Disease development was significantly different among the three types of inoculum (Bs006 cells resuspended in water, supernatant diluted in water at $10 \%$, and a mix of Bs006 cells resuspended in supernatant solution) $(P \leq 0.0001)$ and the volume of application $(P=0.0089)$. The inoculum $\mathrm{x}$ volume interaction was significant $(P \leq 0.0001)$. There was an inverse relationship between the volume of Bs006 cells $\left(1 \times 10^{8}\right.$ cfu.mL $\left.{ }^{-1}\right)$ and the AUDPC incidence, where greater volumes of Bs006 cells led to a lower incidence development. However, all volumes of cell suspension significantly reduced the development of the disease incidence (Fig. 5). The application of $30 \mathrm{~mL}$ of supernatant solution

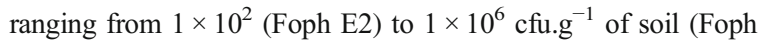
E6). Inoculated soil with Foph and not treated with Bs006 was used as negative control (-Bs006). Columns of each variable with the same letter are significantly not different according to Tukey test $(\alpha=0.05)$. Bars on the columns represent the standard error of the mean $(n=4)$

significantly reduced the disease compared to the negative control, but the disease was higher for all other volumes applied (Fig. 5). Application of mix of cells and supernatant (mix) at all volumes tested significantly reduced the disease incidence compared to the negative control. However, the disease was similar under all volumes of the mix. Moreover, application of 30 and $150 \mathrm{~mL}$ of the mix negatively affected the efficacy of biocontrol since the incidence was significantly lower with $30 \mathrm{~mL}$ of supernatant and $150 \mathrm{~mL}$ of cell suspension, respectively (Fig. 5). Application of 150 mL.plant ${ }^{-1}$ of Bs 006 cells suspension at $1 \times 10^{8}$ cfu.mL $\mathrm{mL}^{-1}$ showed $77 \%$ efficacy in reduction of FW incidence while the efficacy of application of 30 mL.plant ${ }^{-1}$ of supernatant was $66 \%$ and the mix showed 38 to $48 \%$ efficacy. Application of different volumes of water in the control did not reduce neither stimulated the development of the disease compared to the negative control (Supplementary material Fig. S2), therefore the observed effects really are attributed to the biocontrol treatments. 


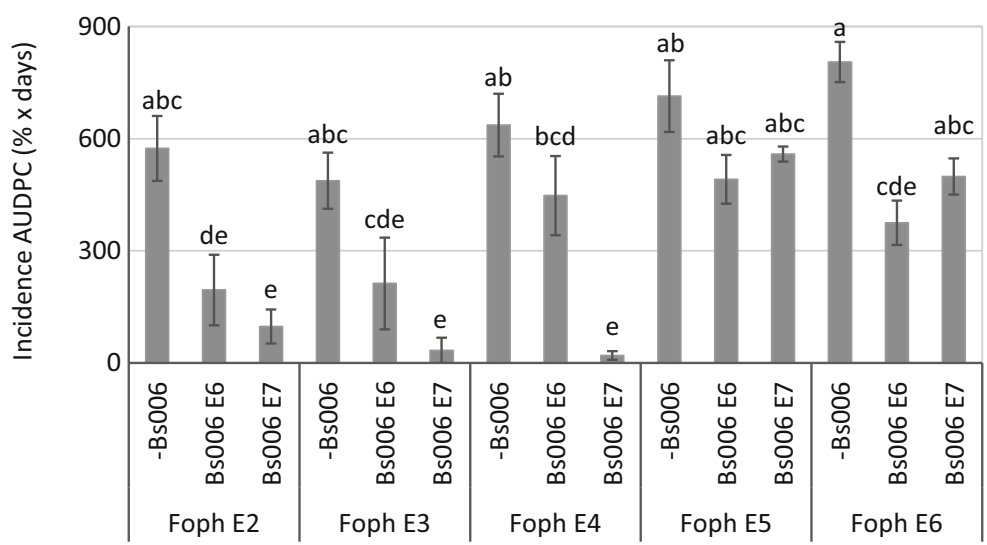

Fig. 4 Effect of low doses of Bs006 $1 \times 10^{6}$ cfu.mL $^{-1}$ (Bs006 E6) and $1 \times 10^{7}$ cfu.mL $\mathrm{mL}^{-1}$ (Bs006 E7) and inoculum density of FophMap5 ranging from $1 \times 10^{2} \mathrm{cfu}^{-1}$ (Foph E2) to $1 \times 10^{6}$ (Foph E6) in non-sterile soil on the Fusarium wilt incidence progress

\section{Effect of concentration of B. velezensis Bs006 on plant} growth

After 30 days of growth in the nursery Bs006 application did not show a significant effect on the length of the main root or the formation of secondary roots (Table 1). However, the application of the bacteria significantly stimulated the height of the plant (length of the main stem), compared to the controls. There were no significant differences among the tested concentrations of Bs006 (Table 1).

In the post-transplant phase, application of Bs006 significantly stimulated plant growth in cape gooseberry
(AUDPC) at 45 days after inoculation (in non-sterile soil). Columns with the same letter are significantly not different according to Tukey test $(\alpha=0.05)$. Bars on the columns represent the standard error of the mean $(n=4)$

at all the doses used, compared to the control. Specifically, Bs006 at $1 \times 10^{7}$ cfu.mL $\mathrm{mL}^{-1}$, significantly increased the leaf area and the shot dry weight compared to the lowest dose of Bs006 evaluated $\left(1 \times 10^{5} \mathrm{cfu}_{\mathrm{mL}}^{-1}\right)$. Surprisingly, the shoot dry weight was significantly higher when Bs006 was applied at $1 \times 10^{7} \mathrm{cfu}_{\mathrm{mL}}^{-1}$ compared to the higher doses (Table 1).

Plant growth promoting activity by Bs006 in presence of the pathogen

In soil free of Foph-Map5, Bs006 significantly stimulated shoot height, leaf area and shot dry weight by 22.0 ,

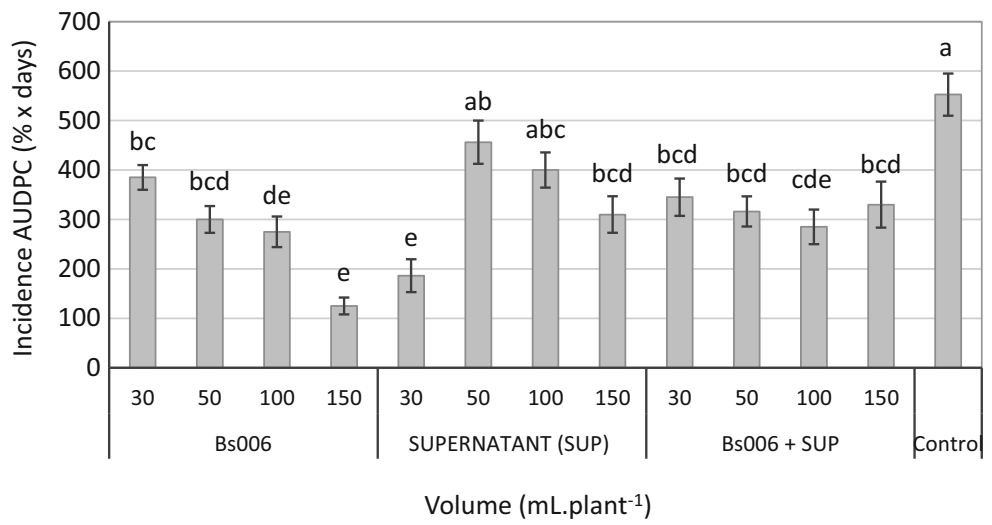

Fig. 5 Area under Fusarium wilt incidence progress curve at 41 days after inoculation (in non-sterile soil) in response to appli-

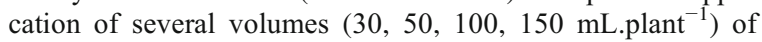
B. velezensis $\mathrm{Bs} 006$ cell suspension (Bs006), filtered-fermented LB broth by Bs006 (SUPERNATANT / SUP) and the mixture of Bs006 cells with supernatant (Bs006 + SUP). Bs006 was grown during $48 \mathrm{~h}$ in $\mathrm{LB}$ broth at $30^{\circ} \mathrm{C}$ and $150 \mathrm{rpm}$. Concentration of
Bs006 cells was adjusted to $1 \times 10^{8}$ cfu. $\mathrm{mL}^{-1}$ while supernatant was used at $10 \%$ in tap water. Control consisted of plants growing in soil inoculated with pathogen and treated with water. Columns with the same letter are significantly not different according to Tukey test $(\alpha=0.05)$. Bars on the columns represent the standard error of the mean $(n=4)$ 
Table 1 Growth response of cape gooseberry (Physalis peruviana) to application of different concentrations of B. velezensis Bs006

\begin{tabular}{|c|c|c|c|c|c|c|}
\hline \multirow[t]{3}{*}{ Treatment $^{\mathrm{a}}$} & \multicolumn{3}{|c|}{ Nursery $^{\mathrm{b}}\left(30\right.$ das $^{\mathrm{c}}$} & \multicolumn{3}{|c|}{ Post-transplant $^{\mathrm{d}}(25 \mathrm{dat})^{\mathrm{c}}$} \\
\hline & \multicolumn{2}{|l|}{ Length $(\mathrm{cm})$} & \multirow[t]{2}{*}{ Secondary roots (No.) } & \multirow[t]{2}{*}{ Foliar area $\left(\mathrm{cm}^{2}\right)$} & \multicolumn{2}{|c|}{ Dry weight (g) } \\
\hline & Root & Stem & & & Root & Shoot \\
\hline $10^{5}$ & $53.9 \pm 5.65 \mathrm{~b}$ & $16.1 \pm 1.46 \mathrm{a}$ & $10.2 \pm 0.34 \mathrm{abc}$ & $212.2 \pm 42.35 \mathrm{~b}$ & $0.5 \pm 0.09 \mathrm{a}$ & $1.3 \pm 0.34 \mathrm{~b}$ \\
\hline $10^{6}$ & $69.0 \pm 14.74 \mathrm{ab}$ & $15.9 \pm 3.17 \mathrm{a}$ & $9.3 \pm 0.46 \mathrm{bc}$ & $233.1 \pm 38.62 \mathrm{ab}$ & $0.5 \pm 0.16 \mathrm{a}$ & $1.4 \pm 0.19 \mathrm{ab}$ \\
\hline $10^{7}$ & $79.3 \pm 3.90 \mathrm{a}$ & $17.6 \pm 1.63 \mathrm{a}$ & $9.6 \pm 0.40 \mathrm{abc}$ & $262.7 \pm 34.54 \mathrm{a}$ & $0.6 \pm 0.21 \mathrm{a}$ & $1.6 \pm 0.23 \mathrm{a}$ \\
\hline $10^{8}$ & $60.5 \pm 26.13 \mathrm{ab}$ & $16.6 \pm 0.83 \mathrm{a}$ & $8.2 \pm 0.40 \mathrm{c}$ & $226.2 \pm 37.01 \mathrm{ab}$ & $0.5 \pm 0.21 \mathrm{a}$ & $1.3 \pm 0.20 \mathrm{~b}$ \\
\hline $10^{9}$ & $72.9 \pm 20.42 \mathrm{ab}$ & $17.1 \pm 0.91 \mathrm{a}$ & $11.5 \pm 0.61 \mathrm{a}$ & $246.9 \pm 42.55 \mathrm{ab}$ & $0.6 \pm 0.07 \mathrm{a}$ & $1.3 \pm 0.14 b$ \\
\hline Control $^{\mathrm{e}}$ & $61.9 \pm 12.53 \mathrm{ab}$ & $12.3 \pm 0.75 b$ & $10.1 \pm 0.51 \mathrm{abc}$ & $136.9 \pm 40.94 \mathrm{c}$ & $0.3 \pm 0.08 \mathrm{~b}$ & $0.9 \pm 0.20 \mathrm{c}$ \\
\hline Fertilizer $^{\mathrm{f}}$ & $74.5 \pm 2.02 \mathrm{ab}$ & $13.0 \pm 1.35 \mathrm{~b}$ & $10.9 \pm 0.63 \mathrm{ab}$ & $210.1 \pm 35.80 \mathrm{~b}$ & $0.5 \pm 0.10 \mathrm{a}$ & $1.3 \pm 0.28 b$ \\
\hline
\end{tabular}

Data correspond to mean \pm standard deviation of 15 (Nursery) and 9 samples (Post-transplant). Significant differences between treatments are indicated by different letters in each variable according to Tukey test $(\alpha=0.05)$

${ }^{\text {a }}$ Evaluation of Bs006 concentrations (cfu. $\mathrm{mL}^{-1}$ ) under nursery and post-transplant phases were carried out in independent experiments

${ }^{\mathrm{b}}$ Bs006 was applied at sown, 1 and 2 weeks after sown. $5 \mathrm{~mL}$ of cell suspension were applied to each seedling

${ }^{\mathrm{c}}$ Days after sowing (das), days after transplant (dat)

${ }^{\mathrm{d}}$ Bs006 was applied once only immediately after transplant. $30 \mathrm{~mL} \cdot$ plant $^{-1}$ were applied. Bs006 treated plants were fertilized with a half dose of nutrient solution

${ }^{\mathrm{e}}$ No treatment was applied to the plants

${ }^{\mathrm{f}}$ Commercial product $\left(\right.$ Tottal $\left.{ }^{\circledR}\right)$ containing major and minor nutrients at dose of $3 \mathrm{~mL} / \mathrm{L}$ were used. $5 \mathrm{~mL}$ of nutrient solution were applied per plant with same frequency as application of the bacteria

27.3 , and $43.1 \%$, respectively, compared to the control but did not stimulate root growth. However, in soil inoculated with Foph-Map5, the growth of plants treated with Bs006 was significantly lower compared to the treated plants grown in soil free of pathogen, but similar to that of the untreated plants in soil free of Foph-Map5 (absolute control) and in pathogen inoculated soil (negative control) (Table 2). Results thus suggested that presence of the pathogen negatively affects plant growth normally promoted by Bs006, nevertheless, it is necessary to elucidate whether the pathogen affects the expression of Bs006 traits or the plant responses.

\section{Endophytic ability of Bs006}

B. velezensis Bs006 was recovered from the rhizosphere as well as from the inner root and stem tissues, at 2 (seedling) and 5 weeks (post-transplant) after

Table 2 Growth of cape gooseberry in presence of $F$. oxysporum f. sp. physali Map5 in the soil at 20 days after-transplant

\begin{tabular}{|c|c|c|c|c|c|c|c|c|}
\hline \multirow[t]{3}{*}{ Treatment } & \multirow{2}{*}{\multicolumn{2}{|c|}{ Shoot height $(\mathrm{cm})$}} & \multirow{2}{*}{\multicolumn{2}{|c|}{ Foliar area $\left(\mathrm{cm}^{2}\right)$}} & \multicolumn{4}{|c|}{ Dry weight (g) } \\
\hline & & & & & \multicolumn{2}{|l|}{ Root } & \multicolumn{2}{|l|}{ Shoot } \\
\hline & -Foph & + Foph & -Foph & + Foph & -Foph & + Foph & -Foph & +Foph \\
\hline Bs006 & $20.7 \pm 1.65 \mathrm{a}$ & $14.2 \pm 2.02 \mathrm{~b}$ & $232.5 \pm 28.57 \mathrm{a}$ & $153.0 \pm 34.70 \mathrm{~b}$ & $0.4 \pm 0.11 \mathrm{a}$ & $0.3 \pm 0.13 b$ & $1.7 \pm 0.42 \mathrm{a}$ & $0.8 \pm 0.21 \mathrm{c}$ \\
\hline Control & $16.1 \pm 2.95 b$ & $13.5 \pm 1.67 b$ & $168.9 \pm 43.92 b$ & $140.4 \pm 34.42 b$ & $0.3 \pm 0.10 \mathrm{ab}$ & $0.3 \pm 0.09 \mathrm{~b}$ & $0.9 \pm 0.34 \mathrm{bc}$ & $0.9 \pm 0.24 \mathrm{c}$ \\
\hline
\end{tabular}

The plants were transplanted in soil free of pathogenic inoculum (-Foph) or artificially inoculated with Foph-Map5 (+Foph) at $1 \times 10^{4}$ cfu. $\mathrm{g}^{-1}$ of soil. B. velezensis Bs006 was applied immediately after transplant $\left(30 \mathrm{~mL}\right.$.plant $\left.{ }^{-1}, 1 \times 10^{8} \mathrm{cfu}^{-\mathrm{mL}^{-1}}\right)$. Seedlings for this experiment were rooted in sterile peat for 60 days applying nutrient solution in dose of 1 to $3 \mathrm{~mL} \cdot \mathrm{L}^{-1}$ once a week from 4 th to 8 th week after sown and no fertilizer were applied after transplant

Data correspond to mean \pm standard deviation of 9 samples. Significant differences between treatments are indicated by different letters of each variable according to Tukey test $(\alpha=0.05)$ 
Fig. 6 Effect of B. velezensis Bs006 dose applied to cape gooseberry seedlings growing in non-sterile substrate on its population in the rhizosphere and tissues. Samples were taken at 30 days after inoculation. Columns of each sampled zone with the same letter are significantly not different according to Tukey test $(\alpha=$ 0.05 ). Bars on the columns represent standard deviation of the mean $(n=9)$

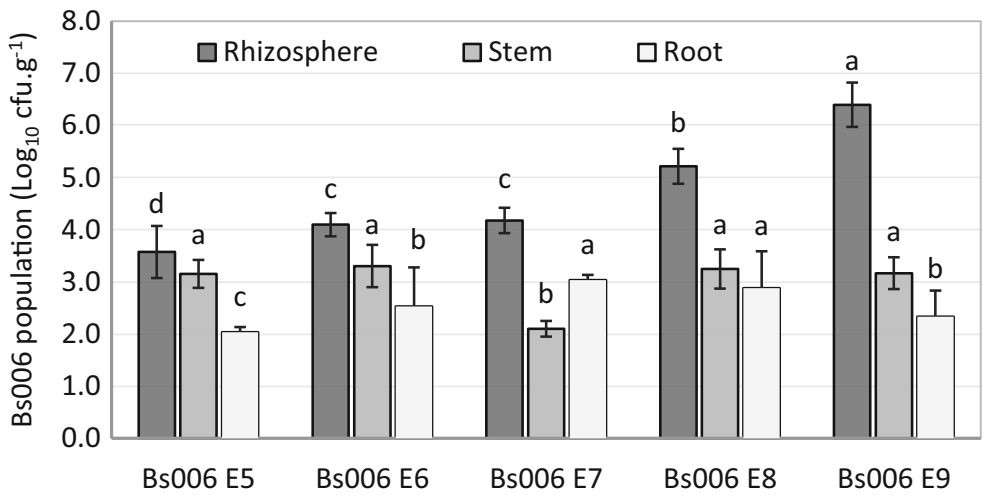

Concentration of Bs006 applied at transplant (cfu.mL $\mathrm{m}^{-1}$ ) application of Bs006 to the substrate. These results demonstrate that the Bs006 acts as an endophyte colonizing the roots and stems of cape gooseberry. Bs006 populations were more numerous in the rhizosphere than inside the seedlings. A positive correlation was identified between the initial concentration of Bs006 cells applied to the substrate and the concentration of bacteria recovered from the rhizosphere (Fig. 6). The population of Bs006 recovered from the lower section of the stem of the seedling was similar among treatments, except for the treatment $1 \times 10^{7}$ cfu.mL $\mathrm{mL}^{-1}$ where the population was significantly lower $(P \leq 0.05)$. In the case of roots of seedlings, it was shown that under low and high concentrations of Bs006 $\left(1 \times 10^{5}, 1 \times 10^{6}\right.$, and $1 \times 10^{9}$ cfu. $\left.\mathrm{mL}^{-1}\right)$, the endophytic population was significantly lower $(P \leq 0.05)$ than when it was applied at the intermediate doses $\left(1 \times 10^{7}\right.$ and $1 \times 10^{8}$ cfu.mL $\left.^{-1}\right)$ (Fig. 6).

In post-transplant assays the density of endophytic population of Bs006 in the main root of cape gooseberry was negatively affected by the presence of Foph-Map5 in the rhizosphere, since the bacteria reached populations from $1 \times 10^{4}$ to $2.7 \times 10^{6} \mathrm{cfu} . \mathrm{g}^{-1}$ of tissue when it was applied in soil free of Foph-Map5, whereas in the presence of the pathogen the population of $\mathrm{Bs} 006$ ranged from $7.5 \times 10^{3}$ to $6.9 \times 10^{4} \mathrm{cfu}^{-g^{-1}}$. In soil free of Foph-Map5 the endophytic population of Bs006 was higher in the root crown $\left(2.7 \times 10^{6} \mathrm{cfu}^{-\mathrm{g}^{-1}}\right)$, followed by the elongation zone $\left(4.3 \times 10^{4} \mathrm{cfu}^{-\mathrm{g}^{-1}}\right)$, whereas in the root apex had the lowest density $\left(1 \times 10^{4} \mathrm{cfu}^{\left.-\mathrm{g}^{-1}\right)}\right.$. In the presence of Foph-Map5 the density of the endophytic population of Bs006 was similar in the root crown and root apex $\left(1.8 \times 10^{4}\right.$ to $\left.6.9 \times 10^{4} \mathrm{cfu}^{-\mathrm{g}^{-1}}\right)$, whereas in the elongation zone the population was lower ( 7.5 to $8.3 \times$ $10^{3}$ cfu-g $^{-1}$ ).

\section{Discussion}

There is a need for rigorous demonstrations of the efficacy of biocontrol agents and to increase use of these products. Greenhouse efficacy tests and field demonstrations are the most persuasive methods to show the effectiveness of biopesticides and are key for adoption by farmers (Glare et al. 2012). In this context, previous evaluations of $B$. velezensis Bs006 showed high variability among experiments. However, there were methodological differences between studies such as the use of autoclaved soil, concentrations, times and volumes of application of Bs006, the culture media used for growing both Bs006 and Foph-Map5, and the period for disease evaluation. Due to this variability, the potential of Bs006 to control FW of cape gooseberry in vivo remained unclear. With the aim of generating a clear perspective about the biocontrol activity of $B$. velezensis Bs006, in this study we determined the effect of soil sterilization, the concentration of both Bs006 and FophMap5, and supernatant of Bs006 on the efficacy of biocontrol against FW. Considering that in the absence of pathogenic inoculum Bs006 has shown consistent plant growth promoting activity, we also tested the influence of the presence of Foph in the soil on plant growth promoting activity of Bs006.

An interesting finding was the negative effect of soil sterilization on the biocontrol activity of $B$. velezensis Bs006. Sterilization of soil was used in this study since soil disinfection by solarization or fumigation of the portion of soil extracted to each planting site is a method that growers could use as a preventive measure against soil-borne phytopathogens before transplanting cape gooseberry. We disinfected the soil by autoclave to 
eliminate populations of microorganisms and with the aim to determine the influence of the native microflora on Bs006 biocontrol activity. Soil disinfection can cause chemical, physical and biological changes, which can positively or negatively affect the growth of plants (Gamliel and Katan 1991). Disinfection of soil by autoclaving is one of the most effective methods to reduce the microbial biomass in soil (Razavi darbar and Lakzian 2007). We analyzed the cultivable populations of bacteria and fungi in soil before and after autoclaving and a significant reduction of microorganisms in autoclaved soil was observed. Population of cultivable bacteria and fungi in natural soil (nonautoclaved) were found at $1.4 \times 10^{6}$ and $1.1 \times$ $10^{4} \mathrm{cfu}^{-\mathrm{g}^{-1}}$ of soil, respectively. While population of bacteria were found $<10 \mathrm{cfu}^{-1}$ and fungi were not detected in autoclaved soil.

Although we did not compare the chemical analysis of natural and autoclaved soil used in this study, we have analyzed other samples of the same andosol. We have observed that $\mathrm{pH}$ of autoclaved soil decreases slightly (from 5.78 to 5.45 ) and the electrical conductivity (EC) increases significantly (from 2.46 to 4.68 ). Other significant changes after autoclaving the soil were the decrease of available sulfur and the increase of available manganese concentration (Supplementary material Table S2). However, cultivated cape gooseberry in autoclaved soil has not shown nutritional deficiencies or toxicities compared to plants cultivated in nonautoclaved soil in our experimental conditions. We have also determined that the growth of Bs006 is not affected by media at $\mathrm{pH}$ from 5 to 9 . This bacterium tolerates high concentrations of sodium $(10 \% \mathrm{NaCl})$, sulfur (2.5\% $\left.\mathrm{CaSO}_{4}\right)$, calcium $\left(5 \% \mathrm{CaCl}_{2}\right)$, iron $(10 \mathrm{mM}$ $\left.\mathrm{FeCl}_{3}\right)$ and aluminum $\left(5 \mathrm{mM} \mathrm{Al}{ }_{3}\left(\mathrm{SO}_{4}\right)_{3}\right)$ in the culture media (Supplementary material Fig. S3). Similarly, F. oxysporum f. sp. physali Map5 is able to grow at $\mathrm{pH}$ from 4 to 9 with an optimum value at $\mathrm{pH}$ 7. This strain tolerates high concentrations of sodium $(10 \% \mathrm{NaCl})$, sulfur $\left(10 \% \mathrm{CaSO}_{4}\right)$, aluminum $\left(10 \mathrm{mM} \mathrm{Al}{ }_{3}\left(\mathrm{SO}_{4}\right)_{3}\right)$ and calcium $\left(10 \% \mathrm{CaCO}_{3}\right)$ in the culture medium. However, its growth is affected by concentrations of $\mathrm{NaCl}$ and $\mathrm{CaSO}_{4}$ above $1 \%$ (Supplementary material Fig. S4). Since concentrations of the mentioned elements are higher than the concentrations present in the soil, it can be assumed that chemical changes in the autoclaved soil did not negatively affect the survival of Bs006 or stimulate the growth of Map5. Since chemical changes in autoclaved soil did not affect the activity of Bs006 and Foph-Map5, the reduction in microorganism populations in the soil could be the main factor that favored the faster development of vascular wilting in cape gooseberry plants grown in autoclaved soil.

Thus, sterile soil may provide less competition for growth of $F$. oxysporum f. sp. physali in the rhizosphere and increase contact with the roots of the host. It is also possible that the native microflora plays a synergistic role with Bs006, to reduce the infections of Foph-Map5 in the roots. It could exert an effect on the pathogen and on natural microbial population that is changing because of the Bacillus introduction. A change in the native population towards more biocontrol activity including induced resistance by this population was demonstrated to take place when Trichoderma BCA was used in soil (Okon Levy et al. 2015). Our result agrees with Abawi and Lorbeer (1972), who showed that biotic factors like the presence of the native microflora and inoculum density of the pathogen determined the potential for the disease development. The authors showed that the germination of conidia and growth of $F$. oxysporum $\mathrm{f}$. sp. cepae and the incidence of the disease in onion seedlings were higher in sterile soil compared to nonsterile soil. They also found that a low concentration of the pathogen (100 propagules. $g^{-1}$ of soil) in sterile soil caused high level of the disease $(76 \%)$ whereas a concentration of inoculum 1000 times higher was needed to cause the same level of the disease in non-sterile soil. The population of $F$. oxysporum conidia in natural soil can suffer a significant reduction due to lysis, or to a lesser extent, the formation of chlamydospores.

Since 1977, the risk of using disinfected soil for the production of tomato has been known, owing to strong epidemics caused by recontamination and fast colonization of the soil by aerial inoculum of microconidia of F. oxysporum f. sp. lycopersici (Rowe et al. 1977). The present study showed higher level of the disease in sterile soil inoculated with microconidia of FophMap5 than in non-sterile soil. Competitive advantages for incoming $F$. oxysporum f. sp. radicis-lycopersici provided by the absence of indigenous microflora was also demonstrated by Kamilova et al. (2006). Additionally, our results show that $F$. oxysporum f. sp. physali in sterile soil conditions also reduce the opportunities of biocontrol by $B$. velezensis Bs006.

Other studies have shown a clear relationship between the efficacy of plant disease control and the dose of the biological control agent applied to the rhizosphere (Smith et al. 1997; Larkin and Fravel 1999; Bressan and 
Fontes 2008). This is a particularly important aspect since it is directly related to the economic viability for implementation of a biopesticide. Nonetheless, few works have studied the development of the disease in response to different combinations between densities of the biocontrol agent and the pathogen. As far as we know, this is the first work studying the dose-response relationship in the system $B$. velezensis - Fusarium wilt disease. Our results differ from those documented by Bressan and Fontes (2008) which describe a significant reduction of the disease caused by $F$. moniliforme in corn under high and low doses of Streptomyces spp. against both high and low concentrations of the pathogen. In the first stage of the present work, it was surprisingly noticed that Bs006 only reduced disease severity in the combination of Bs006 $\left(1 \times 10^{8}\right.$ cfu.mL $\left.\mathrm{mL}^{-1}\right)$ - Foph-Map5 $\left(1 \times 10^{4}\right.$ cfu. $\left.{ }^{-1}\right)$ but not at the highest dose tested $(1 \times$ $10^{9}$ cfu. $\left.\mathrm{mL}^{-1}\right)$. Based on this result, we evaluated the effect of lower doses of Bs006 $\left(1 \times 10^{6}\right.$ and $1 \times 10^{7}$ cfu. $\mathrm{mL}^{-1}$ ) and observed that Bs006 had no significant effects on the disease under high pressure of Foph-Map5 $\left(1 \times 10^{5}\right.$ and $\left.1 \times 10^{6} \mathrm{cfu}^{-g^{-1}}\right)$. However, under regular density of pathogen population in soil $\left(1 \times 10^{2}\right.$ to $\left.1 \times 10^{4} \mathrm{cfu}^{-1}\right)$ (González and Barrero 2011), low doses of Bs006 $\left(1 \times 10^{6}\right.$ cfu. $\mathrm{mL}^{-1}$ and $1 \times 10^{7}$ cfu.mL $\mathrm{mL}^{-1}$ ) showed significant effects of biocontrol (Fig. 4).

It is well known that members of the operational group B. amyloliquefaciens synthesize CLPs and polyketides (PKs) which function as antibiotics with antifungal and antibacterial activity, respectively (Chen et al. 2007). It has already been shown that Bs006 produces compounds of the three families of known CLPs, iturins, surfactins and fengycins as well as PKs in liquid media (Moreno-Velandia et al. 2016). Iturins and fengycins have been shown to have direct negative effects on plant pathogens (Malfanova et al. 2012; Cawoy et al. 2015) whereas surfactins cause an indirect effect through the stimulation of defense responses in the host plant (Ongena et al. 2007; Pertot et al. 2013; Cawoy et al. 2014). There are several possible reasons why higher doses of biocontrol treatment were not found to be more effective in this study. Firstly, a high dose of biocontrol treatment (diluted Bs006-liquid culture) could be associated with high concentration of CLPs leading to a side effect in the plant, thus facilitating the entry of Foph-Map5. Alternately, considering the direct effects of the CLPs and PKs against fungi and bacteria (Ongena and Jacques 2008; Chen et al. 2009), its application could have a soil disinfectant effect whose impact increases with higher doses of biocontrol treatment. In this case, Foph-Map5 microconidia that were not affected by the treatment, may have had the opportunity to quickly colonize the rhizosphere and penetrate the host due to low competition. Additionally, if the cells of the BCA must to be close to, or in contact with the pathogen to cause damage, $30 \mathrm{~mL}$ of biological treatment may not be enough to uniformly cover all the substrate, where Foph-Map5 was, which was suggested when different volumes of Bs006-cells were tested. However, applying high volumes of Bs006supernatant at a concentration of $10 \%$, the antifungal substances produced by Bs006 did not completely inhibit the ability of Foph-Map5 to cause disease and the observed effect of high volumes of Bs006-cells was inhibited in the treatment of Bs006 and supernatant mix. As such, a higher concentration of the active substances may be necessary to cause significant damage to the pathogen. It is also possible that Foph-Map5 presents tolerance to these compounds or that these substances caused a fungistatic but not fungicidal effect in Foph-Map5. These are additional aspects of the interactions between Bs006 and Foph that need to be studied.

Our results allow us to discard that high concentrations of bacterial cells (without supernatant) favor the development of vascular wilt of cape gooseberry caused by Foph-Map5. We showed that high doses of the culture supernatant applied to the rhizosphere was the cause of the mentioned phenomenon. Reasons behind the negative effect caused by high concentrations of supernatant remain unknown. However, phytotoxic effect can be discarded since biocontrol treatment (diluted liquid culture of Bs006) applied at $1 \times 10^{9} \mathrm{cfu}_{\mathrm{mL}}^{-1}$ in previous studies, did not cause adverse reactions in plants grown in soil free of Foph, but rather, has shown plant growth promoting effects (Díaz et al. 2013). In that case the biocontrol treatment contained high concentration of supernatant since the final average concentration of Bs006 cells after $48 \mathrm{~h}$ grown in LB broth is $1,6 \times 10^{9}$ cfu. $\mathrm{mL}^{-1}$. On the other hand, based on the findings of $\mathrm{Du}$ et al. (2017) who reported the elicitation of resistance genes by Paenibacillus polymyxa NSY50 in cucumber root during the early stages of interaction with F. oxysporum f. sp. cucumerinum and reduced expression as the disease developed, thus it is possible that the relationship between concentration of elicitors such a CLPs in Bs006-supernatant and the expression of the 
defense-related genes in the host could have an important role in development of FW of cape gooseberry.

Although it is a poorly explored area, it has already been shown that the effects of beneficial microorganisms on plant growth or against plant pathogens is dependent on the dose of the active substance produced by beneficial microorganisms, and additionally, that the most effective dose may be crop specific (Singh et al. 2016). This is an area that requires further study given that it represents one of the possible sources of variation in results of biological control. Since there may be an optimal dose of active compounds produced by microbes, there may also be a dose that elicits adverse results for the crop. This phenomenon was described recently for Trichoderma asperellum BHUT8, which when was applied in high doses, it caused growth inhibition of some vegetable species (Singh et al. 2016). The secondary metabolites produced by biological control agents can promote plant growth or induce resistance in the host at low concentrations but applied at high doses, may inhibit plant growth (Vinale et al. 2008; Cai et al. 2013; ContrerasCornejo et al. 2016). Recently, Shi et al. (2016) described that the growth inhibition of Arabidopsis roots was induced by Trichokonin VI (peptaibol) produced by Trichoderma longibrachiatum SMF2.

In the absence of pathogenic inoculum, this study demonstrates the potential of Bs006 as a plant growth promoter. However, few studies have reported the effect of the presence of plant pathogens on the plant growth promoting activity. The fact that Bs006 has been isolated from endophytic compartments within plant tissue after introduction in the soil, may suggest that the microorganism is competent in the rhizosphere. We observed that the presence of Foph-Map5 influenced the biocontrol activity, the plant growth promoting activity of Bs006 as well as the endophytic population of Bs006, which suggests that this pathogen can affect the expression of biocontrol, plant growth promoting and colonization traits in the bacteria.

The severity of the epidemics of vascular wilt of carnation are governed mainly by the interaction between various factors such as the host (type and degree of resistance of the crop), the pathogen (race, pathogenicity, virulence and initial concentration of inoculum) and the environment (intensity of solar radiation, photoperiod, temperature and growth substrate) (BenYephet and Shtienberg 1997). In the current work we have addressed aspects related to the pathogen (inoculum concentration) and the environment (sterility of substrate) that affects the development of the disease but at the same time we could observe how these aspects also affect the biocontrol activity of $B$. velezensis Bs006. There is a high interest to determine the factors that affect the biocontrol activity of biological control agents, with the aim to design strategies to increase its activity but, works developed in this topic still are scarce.

To date there are no varieties of cape gooseberry resistant to Foph, although there is a wide number of accessions of plant germplasm that could be used in plant breeding programs (Osorio-Guarín et al. 2016) and several of these show varying degrees of resistance (Rodríguez 2013). From an integrated disease management point of view, it would be interesting to study the development of the disease in response to the interaction of these accessions with Bs006. Furthermore, there is also many pathotypes of Foph associated to cape gooseberry and it would be valuable to study the interaction of Bs006 with these isolates as well. Foph-Map5 is the most virulent isolate from cape gooseberry which may limit efficacy and increase the variability of the biocontrol activity of Bs006.

In summary, this work aimed to elucidate the role of some biotic factors that affect the biocontrol activity of Bs006 against Fusarium wilt of cape gooseberry. The results may suggest that loss of native microflora by soil sterilization practices can reduce the efficacy of Bs006 and explains, in part, the variability observed in previous experiments. The densities of the antagonist as well as the pathogen concentration also constitute biotic factors that influence the activity of Bs006 against FW. Our results have practical implications that are important in the design and implementation of control strategies based on $B$. velezensis Bs006. However, further research is necessary to determine the real impact of supernatant on soil microflora. The risk of favor the pathogen colonization by reduced competence of indigenous microorganisms caused by antimicrobial effect of biofertilizers or biofungicides containing crude supernatant is an important issue to be considered in bioproducts development. Complementary strategies to favor the establishment and activity of biological control agents in the rhizosphere also should be studied.

Acknowledgements C.A. Moreno-Velandia's thesis was supported by a commission studies from AGROSAVIA and a grant from Programa Nacional de Formación de Investigadores, Becas 
Colciencias, Colombia, Doctorado Nacional 567. This work was funded by AGROSAVIA and the Colombian Ministry of Agriculture and Rural Development through TV15 and TV16 agreements. The authors acknowledge Ana Milena Barragán and Sandra Lorena Carmona by technical support during their undergraduate internship and Jorge Argüelles from Biometry Department at AGROSAVIA by statistical support. Also thanks to Drs. Felipe Borrero Echeverry and Stephen Lewis Mosher by critical review of the manuscript.

\section{Compliance with ethical standards}

Conflicts of interest The authors declare no conflicts of interest.

Open Access This article is distributed under the terms of the Creative Commons Attribution 4.0 International License (http:// creativecommons.org/licenses/by/4.0/), which permits unrestricted use, distribution, and reproduction in any medium, provided you give appropriate credit to the original author(s) and the source, provide a link to the Creative Commons license, and indicate if changes were made.

\section{References}

Abawi GS, Lorbeer JW (1972) Several aspects of the ecology and pathology of Fusarium oxysporum f. sp. cepae. Phytopathology 62:870-876. https://doi.org/10.1094/Phyto$62-870$

Ahmad JS, Baker R (1987) Rhizosphere competence of Trichoderma harzianum. Phytopathology 77:182-189

Alabouvette C, Olivain C, L'Haridon F, Aimé S, Steinberg C (2007) Using strains of Fusarium oxysporum to control Fusarium wilts: dream or reality? In: Vurro M, Gressel J (eds) Novel biotechnologies for biocontrol agent enhancement and management. NATO Security through Science Series. Springer, Dordrecht, pp 157-177. https://doi. org/10.1007/978-1-4020-5799-1_8

Bacon CW, Porter JK, Norred WP, Leslie JF (1996) Production of fusaric acid by Fusarium species. Appl Environ Microbiol 62:4039-4043

Barrero LS, Bernal A, Navas A, et al (2013) Generación de valor para el desarrollo competitivo del cultivo de la uchuva como modelo de bioprospección de frutas en Colombia. In: Bioprospección para el desarrollo del sector agropecuario de Colombia. Produmedios, Bogotá, pp 120-162

Ben-Yephet Y, Shtienberg D (1997) Effects of the host, the pathogen, the environment and their interactions, on fusarium wilt in carnation. Phytoparasitica 25:207-216. https://doi. org/10.1007/BF02981734

Bonilla MH, Arias PA, Landínez LM, et al (2009) Agenda prospectiva de investigación y desarrollo tecnológico para la cadena productiva de la uchuva en fresco para exportación en Colombia. Giro Editores Ltda., Bogotá

Borriss R (2011) Use of plant-associated Bacillus strains as biofertilizers and biocontrol agents in agriculture. In: Maheshwari DK (ed) Bacteria in agrobiology: plant growth responses. Springer, Berlin, Heidelberg, pp 41-76. https://doi.org/10.1007/978-3-642-20332-9_3

Borriss R (2015) Bacillus, a plant-beneficial bacterium. In: Lugtenberg B (ed) Principles of plant-microbe interactions. Springer, Cham, pp 379-391. https://doi.org/10.1007/978-3319-08575-3_40

Bosland PW (1988) Fusarium oxysporum a pathogen of many plant species. Adv Plant Pathol 6:281-289. https://doi. org/10.1016/B978-0-12-033706-4.50023-2

Brent KJ, Hollomon DW (2007) Fungicide resistance: the assessment of the risk. FRAC monograph No. 2 second, (revised) edition. Aimprint, United Kingdom

Bressan W, Fontes JE (2008) Efficacy and dose-response relationship in biocontrol of fusarium disease in maize by Streptomyces spp. Eur J Plant Pathol 120:311-316. https://doi.org/10.1007/s10658-007-9220-y

Cai F, Yu G, Wang P, Wei Z, Fu L, Shen Q, Chen W (2013) Harzianolide, a novel plant growth regulator and systemic resistance elicitor from Trichoderma harzianum. Plant Physiol Biochem 73:106-113. https://doi.org/10.1016/j. plaphy.2013.08.011

Campbell CL, Madden LV (1990) Introduction to plant disease epidemiology. John Wiley \& Sons, New York 532 p

Cawoy H, Mariutto M, Henry G, Fisher C, Vasilyeva N, Thonart P, Dommes J, Ongena M (2014) Plant defense stimulation by natural isolates of Bacillus depends on efficient surfactin production. Mol Plant-Microbe Interact 27:87-100. https://doi.org/10.1094/MPMI-09-13-0262-R

Cawoy H, Debois D, Franzil L, de Pauw E, Thonart P, Ongena M (2015) Lipopeptides as main ingredients for inhibition of fungal phytopathogens by Bacillus subtilis/ amyloliquefaciens. Microb Biotechnol 8:281-295. https://doi.org/10.1111/1751-7915.12238

Chandel S, Allan EJ, Woodward S (2010) Biological control of Fusarium oxysporum f.sp. lycopersici on tomato by Brevibacillus brevis. J Phytopathol 158:470-478. https://doi.org/10.1111/j.1439-0434.2009.01635.x

Chen X, Chen XH, Koumoutsi A et al (2007) Comparative analysis of the complete genome sequence of the plant growthpromoting bacterium Bacillus amyloliquefaciens FZB42. Nat Biotechnol 25:1007-1014. https://doi.org/10.1038/nbt1325

Chen XH, Scholz R, Borriss M, Junge H, Mögel G, Kunz S, Borriss R (2009) Difficidin and bacilysin produced by plant-associated Bacillus amyloliquefaciens are efficient in controlling fire blight disease. J Biotechnol 140:38-44. https://doi.org/10.1016/j.jbiotec.2008.10.015

Cochrane SA, Vederas JC (2016) Lipopeptides from Bacillus and Paenibacillus spp.: a gold mine of antibiotic candidates. Med Res Rev 36:4-31. https://doi.org/10.1002/med.21321

Contreras-Cornejo HA, Macías-Rodríguez L, del-Val E, Larsen J (2016) Ecological functions of Trichoderma spp. and their secondary metabolites in the rhizosphere: interactions with plants. FEMS Microbiol Ecol 92:fiw036. https://doi. org/10.1093/femsec/fiw036

Deacon JW (1996) Ecological implications of recognition events in the pre-infection stages of root pathogens. New Phytol 133:135-145. https://doi.org/10.1111/j.1469-8137.1996. tb04349.x

Dean R, Van Kan JAL, Pretorius ZA et al (2012) The top 10 fungal pathogens in molecular plant pathology. Mol Plant Pathol 13: 414-430. https://doi.org/10.1111/j.1364-3703.2011.00783.x 
Díaz A, Smith A, Mesa P, Zapata J (2012) Avances en el control biológico de F. oxysporum. In: Díaz A (ed) Estrategias de control biológico de Fusarium oxysporum en el cultivo de uchuva (Physalis peruviana). Produmedios, Bogotá, pp 7181

Díaz A, Smith A, Mesa P, et al (2013) Control of fusarium wilt in cape gooseberry by Trichoderma koningiopsis and PGPR. In: Pertot I, Elad Y, Ait Barka E, Clément C (eds) IOBC-WPRS Bulletin. 86:89-94

Du N, Shi L, Yuan Y et al (2017) Isolation of a potential biocontrol agent Paenibacillus polymyxa NSY50 from vinegar waste compost and its induction of host defense responses against fusarium wilt of cucumber. Microbiol Res 202:1-10. https://doi.org/10.1016/j.micres.2017.04.013

Estupiñan H, Ossa J (2007) Efecto del agente causal de la marchitez vascular de la uchuva. F. oxysporum en solanaceas y otras especies. Pontificia Universidad Javeriana, Bogotá Colombia. Undergraduate thesis in Microbiology

Fan B, Blom J, Klenk HP, Borriss R (2017) Bacillus amyloliquefaciens, Bacillus velezensis, and Bacillus siamensis form an "operational group $B$. amyloliquefaciens" within the $B$. subtilis species complex. Front Microbiol 8:22. https://doi.org/10.3389 /fmicb.2017.00022

Fischer G, Almanza-merchán PJ, Miranda D (2014) Importancia y cultivo de la Uchuva ( Physalis peruviana L .). Rev Bras Frutic 36:1-15

Folman LB, De Klein MJEM, Postma J, Van Veen JA (2004) Production of antifungal compounds by Lysobacter enzymogenes isolate $3.1 \mathrm{~T} 8$ under different conditions in relation to its efficacy as a biocontrol agent of Pythium aphanidermatum in cucumber. Biol Control 31:145-154. https://doi.org/10.1016/j.biocontrol.2004.03.008

Gámez R, Rodríguez F, Bernal JF et al (2015) Genome sequence of the banana plant growth-promoting rhizobacterium Bacillus amyloliquefaciens BS006. Genome Announc 3: 2013-2014. https://doi.org/10.1128/genomeA.01391-15. Copyright

Gamliel A, Katan J (1991) Involvement of fluorescent pseudomonads and other microorganisms in increased growth-response of plants in solarized soils. Phytopathology 81:494-502

Glare T, Caradus J, Gelernter W, Jackson T, Keyhani N, Köhl J, Marrone P, Morin L, Stewart A (2012) Have biopesticides come of age? Trends Biotechnol 30:250-258. https://doi. org/10.1016/j.tibtech.2012.01.003

González C, Barrero LS (2011) Estudio de la marchitez vascular de la uchuva para el mejoramiento genético del cultivo. Cámara de Comercio de Bogotá. Bogotá $44 \mathrm{p}$

Kamilova F, Kravchenko LV, Shaposhnikov AI, Makarova N, Lugtenberg B (2006) Effects of the tomato pathogen Fusarium oxysporum f. sp. radicis-lycopersici and of the biocontrol bacterium Pseudomonas fluorescens WCS365 on the composition of organic acids and sugars in tomato root exudate. Mol Plant-Microbe Interact 19:1121-1126. https://doi.org/10.1094/MPMI-19-1121

Larkin RP, Fravel DR (1999) Mechanisms of action and doseresponse relationships governing biological control of fusarium wilt of tomato by nonpathogenic Fusarium spp. 89: $1152-1161$

Lazarovits G, Turnbull A, Johnston-Monje D (2014) Plant health management: Biological control of plant pathogens. Elsevier
Ltd. Encyclopedia of Agriculture and Food Systems, Volume 4. 388-399. Elsevier Ltd. https://doi.org/10.1016/B978-0444-52512-3.00177-7

Leslie J, Xu J-R (2010) Fusarium genetics and pathogenicity. In: Borkovich K, Ebbole D (eds) Cellular and molecular biology of filamentous fungi. ASM Press, Washington DC, pp 607621

Li L, Ma J, Li Y, Wang Z, Gao T, Wang Q (2012) Screening and partial characterization of Bacillus with potential applications in biocontrol of cucumber fusarium wilt. Crop Prot 35:2935. https://doi.org/10.1016/j.cropro.2011.12.004

Ma L-J, van der Does HC, Borkovich KA, Coleman JJ, Daboussi MJ, di Pietro A, Dufresne M, Freitag M, Grabherr M, Henrissat B, Houterman PM, Kang S, Shim WB, Woloshuk C, Xie X, Xu JR, Antoniw J, Baker SE, Bluhm BH, Breakspear A, Brown DW, Butchko RAE, Chapman S, Coulson R, Coutinho PM, Danchin EGJ, Diener A, Gale LR, Gardiner DM, Goff S, Hammond-Kosack KE, Hilburn K, Hua-van A, Jonkers W, Kazan K, Kodira CD, Koehrsen M, Kumar L, Lee YH, Li L, Manners JM, Miranda-Saavedra D, Mukherjee M, Park G, Park J, Park SY, Proctor RH, Regev A, Ruiz-Roldan MC, Sain D, Sakthikumar S, Sykes S, Schwartz DC, Turgeon BG, Wapinski I, Yoder O, Young S, Zeng Q, Zhou S, Galagan J, Cuomo CA, Kistler HC, Rep M (2010) Comparative genomics reveals mobile pathogenicity chromosomes in fusarium. Nature 464:367-373. https://doi.org/10.1038/nature08850

Malfanova N, Franzil L, Lugtenberg B, Chebotar V, Ongena M (2012) Cyclic lipopeptide profile of the plant-beneficial endophytic bacterium Bacillus subtilis HC8. Arch Microbiol 194:893-899. https://doi.org/10.1007/s00203-012-0823-0

Ministerio de Agricultura C (2016) Agronet-Colombia. In: Red Inf. y Comun. del Sect. Agropecu

Moreno-Velandia C, Kloepper J, Ongena M, et al (2016) Influence of temperature and culture media on growth, lipopeptide production and antagonistic activity of Bacillus amyloliquefaciens Bs006. In: Bardin M, Köhl J (eds) IOBC-WPRS Bulletin. p 161

Okon Levy N, Meller Harel Y, Haile ZM, Elad Y, Rav-David E, Jurkevitch E, Katan J (2015) Induced resistance to foliar diseases by soil solarization and Trichoderma harzianum. Plant Pathol 64:365-374. https://doi.org/10.1111/ppa.12255

Ongena M, Jacques P (2008) Bacillus lipopeptides: versatile weapons for plant disease biocontrol. Trends Microbiol 16: 115-125. https://doi.org/10.1016/j.tim.2007.12.009

Ongena M, Jourdan E, Adam A, Paquot M, Brans A, Joris B, Arpigny JL, Thonart P (2007) Surfactin and fengycin lipopeptides of Bacillus subtilis as elicitors of induced systemic resistance in plants. Environ Microbiol 9:1084-1090. https://doi.org/10.1111/j.1462-2920.2006.01202.x

Ongena M, Henry G, Thonart P (2009) The roles of cyclic Lipopeptides in the biocontrol activity of Bacillus subtilis. Recent Dev Manag Plant Dis:59-69. https://doi.org/10.1007 /978-1-4020-8804-9

Osorio-Guarín JA, Enciso-Rodríguez FE, González C, FernándezPozo N, Mueller LA, Barrero LS (2016) Association analysis for disease resistance to Fusarium oxysporum in cape gooseberry (Physalis peruviana L). BMC Genomics 17:248. https://doi.org/10.1186/s12864-016-2568-7

Pertot I, Puopolo G, Hosni T, Pedrotti L, Jourdan E, Ongena M (2013) Limited impact of abiotic stress on surfactin 
production in planta and on disease resistance induced by Bacillus amyloliquefaciens S499 in tomato and bean. FEMS Microbiol Ecol 86:505-519. https://doi.org/10.1111/15746941.12177

Razavi darbar S, Lakzian A (2007) Evaluation of chemical and biological consequences of soil sterilization methods. Casp J Environ Sci 5:87-91

Rodríguez E (2010) Aislamiento y caracterización de cepas de Fusarium oxysporum en uchuva (Physalis peruviana) y evaluación de la patogenicidad en invernadero. Universidad de Cundinamarca, Fusagasugá, Colombia. Undergraduate thesis in Agronomy

Rodríguez E (2013) Caracterización de aislamientos de Fusarium spp. obtenidos de zonas productoras de uchuva (Physalis peruviana) en Cundinamarca y Boyacá. Universidad Nacional de Colombia, Bogotá. MSc thesis in phytopathology

Rowe R, Farley J, Coplin D (1977) Airborne dispersal and recolonization of steamed soil by Fusarium oxysporum in tomato greenhouses. Dis Control pest Manag 67:1513-1517

Sánchez M, Forero P (2009) Reporte de especies del género Fusarium asociados a la uchuva (Physalis pruviana) y descripción de la etiología relacionada con la fusariosis. Universidad Militar Nueva Granada, Bogotá, Colombia. Undergraduate thesis in Biology

Schouten A, van den Berg G, Edel-Hermann V, Steinberg C, Gautheron N, Alabouvette C, de Vos CH (Ric), Lemanceau P, Raaijmakers JM (2004) Defense responses of Fusarium oxysporum to 2,4-diacetylphloroglucinol, a broad-spectrum antibiotic produced by Pseudomonas fluorescens. Mol PlantMicrobe Interact 17:1201-1211

Shi WL, Chen XL, Wang LX, Gong ZT, Li S, Li CL, Xie BB, Zhang W, Shi M, Li C, Zhang YZ, Song XY (2016) Cellular and molecular insight into the inhibition of primary root growth of Arabidopsis induced by peptaibols, a class of linear peptide antibiotics mainly produced by Trichoderma spp. J Exp Bot 67:2191-2205. https://doi.org/10.1093/jxb/erw023

Simbaqueba J, Catanzariti A-M, González C, Jones DA (2018) Evidence for horizontal gene transfer and separation of effector recognition from effector function revealed by analysis of effector genes shared between cape gooseberry- and tomato-infecting formae speciales of Fusarium oxysporum. Mol Plant Pathol 9:2302-2318. https://doi.org/10.1111 /mpp. 12700

Singh V, Sanmukh R, Kumar B, Bahadur H (2016) Trichoderma asperellum spore dose depended modulation of plant growth in vegetable. Crops 193:74-86

Smith KP, Handelsman J, Goodman RM (1997) Modeling doseresponse relationships in biological control: partitioning host responses to the pathogen and biocontrol agent. Phytopathology 87:720-729. https://doi.org/10.1094 /PHYTO.1997.87.7.720

Thatcher LF, Manners JM, Kazan K (2009) Fusarium oxysporum hijacks COI1-mediated jasmonate signaling to promote disease development in Arabidopsis. Plant J 58:927-939. https://doi.org/10.1111/j.1365-313X.2009.03831.x

Van Dam P, Fokkens L, Schmidt SM et al (2016) Effector profiles distinguish formae speciales of Fusarium oxysporum. Environ Microbiol 18:4087-4102. https://doi.org/10.1111 /1462-2920.13445

Vinale F, Sivasithamparam K, Ghisalberti EL, Marra R, Woo SL, Lorito M (2008) Trichoderma-plant-pathogen interactions. Soil Biol Biochem 40:1-10. https://doi.org/10.1016/j. soilbio.2007.07.002

Zapata J, Díaz A (2012) Evaluaciones en invernadero y selección de prototipos a base de rizobacterias. In: Díaz A (ed) Estrategias de control biológico de Fusarium oxysporum en el cultivo de uchuva (Physalis peruviana). Produmedios, Bogotá, pp 62-70

Zapata J, Díaz A, Caviedes D (2012) Aislamiento y caracterización de rizobacterias. In: Díaz A (ed) Estrategias de control biológico de Fusarium oxysporum en el cultivo de uchuva (Physalis peruviana). Produmedios, Bogotá, pp 2731

Zhang J, Howell CR, Starr JL (1996) Suppression of Fusarium colonization of cotton roots and fusarium wilt by seed treatments with Gliocladium virens and Bacillus subtilis. Biocontrol Sci Tech 6:175-188. https://doi.org/10.1080 /09583159650039377 